\title{
TRADITIONS IN WORLD CINEMA
}

General editors: Linda Badley and R. Barton Palmer Founding editor: Steven Jay Schneider

Traditions in World Cinema is a series of textbooks and monographs devoted to the analysis of currently popular and previously underexamined or undervalued film movements from around the globe. Also intended for general interest readers, the textbooks in this series offer undergraduate- and graduate-level film students accessible and comprehensive introductions to diverse traditions in world cinema. The monographs open up for advanced academic study more specialised groups of films, including those that require theoretically-oriented approaches. Both textbooks and monographs provide thorough examinations of the industrial, cultural, and socio-historical conditions of production and reception.

The flagship textbook for the series includes chapters by noted scholars on traditions of acknowledged importance (the French New Wave, German Expressionism), recent and emergent traditions (New Iranian, post-Cinema Novo), and those whose rightful claim to recognition has yet to be established (the Israeli persecution film, global found footage cinema). Other volumes concentrate on individual national, regional or global cinema traditions. As the introductory chapter to each volume makes clear, the films under discussion form a coherent group on the basis of substantive and relatively transparent, if not always obvious, commonalities. These commonalities may be formal, stylistic or thematic, and the groupings may, although they need not, be popularly 
identified as genres, cycles or movements (Japanese horror, Chinese martial arts cinema, Italian Neorealism). Indeed, in cases in which a group of films is not already commonly identified as a tradition, one purpose of the volume is to establish its claim to importance and make it visible (East Central European Magical Realist cinema, Palestinian cinema).

Textbooks and monographs include:

- An introduction that clarifies the rationale for the grouping of films under examination

- A concise history of the regional, national, or transnational cinema in question

- A summary of previous published work on the tradition

- Contextual analysis of industrial, cultural and socio-historical conditions of production and reception

- Textual analysis of specific and notable films, with clear and judicious application of relevant film theoretical approaches

- Bibliograph(ies)/filmograph(ies)

Monographs may additionally include:

- Discussion of the dynamics of cross-cultural exchange in light of current research and thinking about cultural imperialism and globalisation, as well as issues of regional/national cinema or political/ aesthetic movements (such as new waves, postmodernism, or identity politics)

- Interview(s) with key filmmakers working within the tradition. 


\section{To Peter}

for all the work, the help, the fun:

'Amo i film divertenti e, al contrario di Umberto Barbaro che va al cinema soltanto per istruirsi, io preferisco andarci per dimenticare quel poco che so.' Ennio Flaiano, 1948 